\title{
O POTRZEBIE RÓŻNORODNOŚCI W PRAWIE PRACY
}

\begin{abstract}
Streszczenie. Panuje przekonanie, że skoro prawo pracy ma chronić pracownika, to ze swojej istoty wymaga ograniczeń. Zasada swobody umów powinna być zatem limitowana. W przeciwnym bowiem wypadku dojdzie do naruszenia systemu prawa pracy. Stąd tylko krok do stwierdzenia, że wolność w prawie pracy może stanowić zagrożenie dla realizacji podstawowej funkcji w prawie pracy. Innymi słowy, im większy uniformizm, czyli jednolitość instytucji, tym większa pewność skuteczności działania funkcji ochronnej prawa pracy. Tymczasem funkcja ochrony pracownika nie może i nie powinna stanowić bariery dla rozwoju prawa pracy. Prawo pracy XXI wieku wymaga różnorodności. Tylko dzięki nowym formom zatrudnienia i organizacji pracy oraz elastyczności można sprostać wyzwaniom rynku pracy.
\end{abstract}

Słowa kluczowe: swoboda umów, prawo pracy, wolność, różnorodność, jednolitość, rynek pracy.

\section{FUNKCJA OCHRONNA A RÓŻNORODNOŚĆ}

Z funkcji ochronnej prawa pracy można wyprowadzić prosty, lecz zarazem błędny wniosek, że zbytnia różnorodność lub zbyt daleko posunięta dyferencjacja mogą zagrozić bytowi tej gałęzi prawa. Mówiąc inaczej, w różnorodności można się zagubić i przestać nad nią panować, a w konsekwencji zatracić sens instytucji ochronnych. To nie w pełni przemyślane założenie zapewne rodzi się również z potrzeby odrębności i samodzielności prawa pracy, a konkretnie oderwania tej dyscypliny od prawa cywilnego. Stąd jednak tylko krok do stwierdzenia, że wolność w prawie pracy może stanowić zagrożenie dla realizacji podstawowej funkcji w prawie pracy. Innymi słowy, im większy uniformizm, czyli jednolitość instytucji, tym większa pewność skuteczności działania funkcji ochronnej prawa pracy. Taki pogląd został zresztą wprost wyrażony w literaturze w następujących słowach: „Należy ponadto podkreślić, że uniformizm zwiększa pewność utrzymania osiągniętego poziomu przyznanych przez ustawodawcę uprawnień pracowniczych oraz utrudnia wycofywanie się z przyjętych rozwiązań" (Dral 2017). Inni autorzy twierdzą, że zasada uniformizmu prowadzi do synchronizacji realizacji założonych celów (Salwa 2007). Pojawiają się również opinie, że jedynie dzięki całkowitej jednolitości można osiągnąć ideał równego traktowania w zatrudnieniu,

* Uniwersytet Kardynała Stefana Wyszyńskiego w Warszawie, Wydział Prawa i Administracji, Katedra Prawa Pracy, gladoch_law@wp.pl 
a to z kolei prowadzi do wniosku, że „, prawie pracy nie ma rozwiązań indywidualnych. Każde rozwiązanie wynegocjowane lub wprowadzone dla osoby A musi być zastosowane w stosunku do osoby B, jeśli znajduje się ona w takiej samej sytuacji faktycznej” (Sobczyk 2017).

Przytoczone powyżej refleksje oparte są na założeniu, że prawo pracy wymaga ze swojej istoty ograniczeń, a tym samym także zasada swobody umów musi być limitowana. W przeciwnym bowiem przypadku dojdzie do zachwiania systemu prawa pracy. Założenie powinno wynikać z określonej zasady. Ta jednak jest dokładnie przeciwna: swoboda umów w prawie pracy istnieje, a jej ograniczenie jest możliwe tylko w przypadkach wyraźnie wskazanych w przepisach. Dominujące w prawie pracy przepisy jednostronnie bezwzględnie obowiązujące „nie eliminują swobody kontraktowania, a jedynie ją ograniczają w interesie pracowników” (Sanetra 2017). Jak słusznie zauważono w literaturze, „Swoboda stron przy ustalaniu treści umowy o pracę zależy od zakresu i charakteru przepisów prawa regulujących tę treść. [...] W konsekwencji do tego, co może umowa, nierzadko dochodzi się stopniowo, nie bez sporów i trudności” (Florek 2017, przytoczony in extenso szeroki fragment za: Florek 2012).

Funkcja ochronna prawa pracy nie może i nie powinna stanowić bariery dla rozwoju prawa pracy w celu realizacji postulatu różnorodności. Można jednak odnieść wrażenie, że najmniejsza próba poluzowania ograniczeń kończy się niepowodzeniem. Koronnym argumentem niezmiennie pozostaje postulat konieczności ochrony pracownika, jako słabszej strony stosunku pracy․ Truizmem jest stwierdzenie, że skoro zmienia się otoczenie społeczno-gospodarcze, to i przepisy prawa pracy powinny podlegać ewolucji. Problem jednak w tym, że kurczowe odwoływanie się do wybranej funkcji i to w sposób dość zawężony i intencjonalny, powoduje paraliż rozwoju jakiejkolwiek instytucji w prawie pracy. Efekt jest taki, że prawo pracy pozostaje w defensywie do nowych cywilnoprawnych form zatrudnienia. I nie chodzi tylko o niższe koszty czy mniejszy zakres ochrony pracownika, lecz nierzadko właśnie o wolność wyboru stron, a zatem prawo do różnorodności w procesie kształtowania ich sytuacji prawnej, wynikające z różnych, nie zaś jednakowych potrzeb. Wydaje się, że doktryna prawa pracy jest już pogodzona $\mathrm{z}$ brakiem możliwości zmiany regulacji. Wynika to zapewne z przeświadczenia, że wolność i różnorodność to domena prawa cywilnego. Autorzy zwracają zarazem uwagę na potrzebę funkcjonowania różnych form zatrudnienia, opowiadając się za utrzymaniem dychotomii umów na rynku pracy (zob. m.in. Kijowski 2002; Wagner 2016). Jest to niezbędne choćby dlatego, że nie każdy zatrudniony chce być pracownikiem. Autorzy sugerują jednocześnie potrzebę wprowadzania przepisów ochronnych do umów prawa cywilnego. W mojej ocenie, postulat niesie ze sobą duże ryzyko. Może to bowiem w dalszej perspektywie doprowadzić

${ }^{1}$ Taka refleksja narzuca mi się po dziesięcioletniej pracy w zespołach Trójstronnej Komisji, a obecnie Rady Dialogu Społecznego. 
do rezygnacji z umów prawa pracy i wyboru cywilnoprawnych podstaw zatrudnienia (Gładoch 2015).

Pomimo przywołanych wcześniej wypowiedzi przedstawicieli doktryny, wyrażam jednak dość śmiały pogląd, że prawo pracy można zmienić w kierunku większej swobody kształtowania treści stosunku pracy. W jaki sposób osiągnąć tę różnorodność? Nasuwają się dwa rozwiązania. Pierwsze, które opiera się na zaufaniu do stron stosunku pracy i wiąże się z szerszą możliwością kreowania wzajemnych relacji. W tym przypadku przepis ma charakter raczej ogólny i pozostawia stronom prawo wyboru zgodnie z ich potrzebami. Ta metoda może jednak spotkać się z daleko idącą krytyką, która wynika z przeświadczenia, że obowiązkiem państwa jest ingerowanie w stosunki między pracodawcami a pracownikami, w celu zapewnienia równowagi w tych stosunkach i zapobieżenia wyzyskowi słabszych przez silniejszych. „Ta ingerencja ma przede wszystkim postać norm prawnych ograniczających swobodę umów o zatrudnienie" (Liszcz 2013), co jest spowodowane całkowitym brakiem zaufania do odpowiedzialnych decyzji pracodawcy, uwzględniających choćby w minimalnym stopniu dobro pracownika. Drugie z proponowanych rozwiązań także przewiduje wybór, ale w określonych ramach - w postaci kilku możliwych wariantów lub z użyciem wyjątków przewidzianych w przepisie. Przykładem pierwszej metody regulacji jest umowa o zakazie konkurencji. Nie przypadkiem zresztą, skoro jej rodowód jest cywilistyczny (Gersdorf 2016). Drugi rodzaj regulacji jest charakterystyczny dla przepisów o czasie pracy czy też dopuszczalności zawierania umowy o pracę na czas określony. Nie da się w tym przypadku zaprzeczyć, że wybór sposobu uregulowania relacji istnieje, jednak jest ściśle określony.

W ostatnich latach zwraca się szczególną uwagę na możliwość liberalizacji przepisów prawa pracy w drodze układowej. Jak się okazuje, jest to postulat mający niewielkie zastosowanie w polskich warunkach, przede wszystkim z uwagi na brak reprezentacji pracowniczej w większości zakładów pracy. Pojawia się tu także inny problem, zaledwie zasygnalizowany w polskim piśmiennictwie przez L. Florka, który zauważa: „Nie można różnicować pozycji pracodawców w zakresie możliwości liberalizacji prawa pracy, uzależniając je od tego, czy działają u nich związki zawodowe. Nie można też wymagać od pracodawców, aby inspirowali tworzenie związków zawodowych dla korzystania z uelastycznienia prawa pracy" (Florek 2003).

Niniejsze opracowanie ma na celu zachęcenie do refleksji nad przyszłością prawa pracy. Czy ta gałąź prawa zmierza w kierunku wolności i zaufania czy raczej dalszej reglamentacji i potrzeby ciągłego nadzoru państwa nad warunkami pracy? Druga droga wiedzie prawo pracy ku prawu administracyjnemu, gdzie wolność pracownika musi być uzasadniona potrzebami większości lub ogółu i gdzie państwo ma legitymację do decydowania o dobrostanie wszystkich zatrudnionych. Zaprzecza ona zarazem tendencjom na rynku pracy, które wymagają otwarcia prawa pracy na różnorodność, a nie jednolitość regulacji. Ponadto niesie 
ze sobą niebezpieczeństwo przeregulowania, a zatem zbyt dużej ingerencji państwa w stosunki zatrudnienia, podczas gdy powinna się ona raczej koncentrować na zapewnieniu ,ochrony pracy, a nie na aktywnym i szerokim kształtowaniu warunków jej wykonywania" (Sanetra 1998).

Dyskusja nad sposobem regulacji norm prawa pracy trwa od wielu lat, jednak w obecnym czasie nabiera szczególnego znaczenia. Wpisuje się bowiem w szerszy dyskurs na temat wolności człowieka i jego godności, a zarazem roli państwa i prawa. Zdaję sobie oczywiście sprawę z wymogów zawartych w Konstytucji RP, a także w normach prawa międzynarodowego i europejskiego. Nie jest moim celem stawianie tez obrazoburczych lub całkowicie nierealnych. Jestem jednak przekonana, że prawo pracy powinno się zmieniać, w mojej ocenie raczej w kierunku wolności niż jej ograniczania.

\section{DYFERENCJACJAA RÓŻNORODNOŚĆ}

W nauce prawa pracy „dyferencjację” charakteryzuje się na ogół jako wynikające z normy prawnej aksjologicznie uzasadnione zróżnicowanie statusu prawnego podmiotów prawa (Łaga 2016). M. Święcicki kryteria dyferencjacji ujął w trzech grupach: okoliczności dotyczących świadczonej pracy; okoliczności dotyczących osoby pracownika i okoliczności dotyczących zakładu pracy (Święcicki 1968). Dyferencjacja oznacza zatem różnicowanie z uwagi na określoną sytuację, która ponadto posiada społeczne uzasadnienie. Jak wyjaśniono w piśmiennictwie: „W ujęciu aksjologicznym zjawisko dyferencjacji jest wyrazem wartości leżących u podłoża samego systemu prawnego, ze sprawiedliwością jako fundamentalną wartością współczesnych systemów prawnych" (Łaga 2016).

Pojęcie to nie jest zatem tożsame z terminem „różnorodność”, który w potocznym rozumieniu oznacza „złożenie z kilku elementów, inaczej rozmaitość” (Słownik języka polskiego 1998). W tym ujęciu różnorodność stanowi zatem antonim jednolitości, inaczej uniformizmu. Różnorodność także posiada własną aksjologię, która oparta jest na potrzebie wolności wyboru i związanej z nią możliwości kształtowania treści stosunku pracy z uwzględnieniem potrzeb obu stron. Intencja poszerzenia różnorodności może być zatem odmienna od celu dyferencjacji. Poza tym, o ile dyferencjacja jest cechą systemu prawa pracy, o tyle różnorodność - jego celowo zapomnianym elementem, mimo bowiem zasady semiimperatywnego charakteru norm prawa pracy, w dalszym ciągu obowiązuje swoboda umów.

$Z$ porównania różnorodności i dyferencjacji w prawie pracy wynika pewien paradoks. Znamienne jest bowiem, że z zakazem dyskryminacji wiąże się potrzeba otwartości na różnorodność (odmienność, inność), innymi słowy obowiązek akceptacji różnorodności po stronie pracowników. Już jednak w sferze regulacyjnej, czyli w zakresie kształtowania statusu prawnego podmiotów, w jej miejsce 
wstępuje zasada równego traktowania, która wymaga usprawiedliwienia dla różnorodności. W konsekwencji ustawodawca tłumaczy potrzebę odmiennego traktowania określonych grup podmiotów w prawie pracy. Zgodnie z art.18 ${ }^{3 \mathrm{~b}} \S 2$ k.p. zasady równego traktowania w zatrudnieniu nie naruszają działania, są proporcjonalne do osiągnięcia zgodnego z prawem celu różnicowania sytuacji pracownika, polegające na: 1) niezatrudnianiu pracownika z jednej lub kilku przyczyn, jeżeli rodzaj pracy lub warunki jej wykonywania powodują, że przyczyna lub przyczyny wymienione w tym przepisie są rzeczywistym i decydującym wymaganiem zawodowym stawianym pracownikowi; 2) wypowiedzeniu pracownikowi warunków zatrudnienia w zakresie wymiaru czasu pracy, jeżeli jest to uzasadnione przyczynami niedotyczącymi pracowników, bez powoływania się na inną przyczynę lub inne przyczyny wymienione w art. $\left.18^{3 a} \S 1 ; 3\right)$ stosowaniu środków, które różnicują sytuację prawną pracownika, ze względu na ochronę rodzicielstwa lub niepełnosprawność; 4) stosowaniu kryterium stażu pracy przy ustalaniu warunków zatrudniania i zwalniania pracowników, zasad wynagradzania i awansowania oraz dostępu do szkolenia w celu podnoszenia kwalifikacji zawodowych, co uzasadnia odmienne traktowanie pracowników ze względu na wiek. Powyższe wyjątki określa się w piśmiennictwie mianem ,kontratypów zakazu dyskryminacji” (Wujczyk 2016).

\section{OBOWIĄZEK RÓWNEGO TRAKTOWANIA A RÓŻNORODNOŚĆ}

Radykalne rozumienie obowiązku równego traktowania prowadzi do błędnego wniosku, że jakiekolwiek różnicowanie sytuacji prawnej pracowników znajdujących się w podobnej sytuacji faktycznej i prawnej jest bezprawne. Zasada sprawiedliwości będąca fundamentem zasady równości i niedyskryminacji - jak wyjaśnia Trybunał Konstytucyjny - ,zakłada istnienie proporcji pomiędzy istotnymi cechami poszczególnych kategorii osób a należnym im traktowaniem - zasada relewantności”" (wyrok TK z 6.04.1993 r., K 7/92, OTK 1993, Nr 1, poz. 7). Co więcej, to właśnie zasada sprawiedliwości stanowi czynnik ograniczający możliwość traktowania wszystkich w jednakowy sposób (Wujczyk 2016). Trybunał Konstytucyjny podkreśla, że prawo pracy musi odmiennie kształtować sytuację poszczególnych pracowników ze względu na wykonywaną przez nich pracę, a także ich cechy osobowe (wyrok TK z 19.02.2001 r., SK 14/00, OTK 2001, Nr 2, poz. 31).

Trybunał wymaga namysłu i głębszej refleksji w stosowaniu zasady równego traktowania, stwierdzając: „Nie każde bowiem nierówne traktowanie stanowi jednocześnie naruszenie zasady równości i zasady sprawiedliwości społecznej" (wyrok TK z 24.04.2002 r., P 5/01, OTK-A 20-02, Nr 3, poz. 28). Organ ten dopuszcza zatem zarówno różnicowanie (dyferencjację), jak i różnorodność. Trudno zresztą nie zgodzić się z poglądem Trybunału, skoro sam przepis regulujący zakaz nierównego traktowania wprost przewiduje różnicowanie sytuacji pracowników 
ze względu na odmienności wynikające $\mathrm{z}$ ich cech osobistych i różnic w wykonywaniu pracy. Zgodnie $\mathrm{z}$ art. $11^{2} \mathrm{k}$.p., pracownicy mają równe prawa $\mathrm{z}$ tytułu jednakowego wypełniania takich samych obowiązków.

\section{UNIFORMIZM A RÓŻNORODNOŚĆ}

Uniformizm, w odróżnieniu od zasady równego traktowania, usprawnia realizację określonych celów społecznych ustawodawcy. Polega on na narzucaniu odgórnych zasad przez państwo, które samo ustala, co jest dobre dla pracowników. Rodzi zatem wiele kontrowersji o charakterze aksjologicznym. Ten, kto ma władzę, ten kwalifikuje potrzeby wymagające regulacji prawnej, a następnie wprowadza je w życie. Uniformizacja odbywa się na różnych poziomach: krajowym, europejskim i międzynarodowym. Na ogół, co stanowi oczywistą wartość prawa pracy, gwarantuje pracownikom standardy zatrudnienia, czyli humanizuje pracę. Zdarza się jednak, co dotyczy przede wszystkim norm krajowych, że państwo wkracza $\mathrm{w}$ relacje między stronami stosunku pracy tak dalece, że je zawłaszcza. Jest to proces obserwowany w polskim systemie prawa pracy od okresu powojennego aż po czasy współczesne (Sanetra 2001). W latach 90. ubiegłego wieku przedstawiciele teorii prawa pracy stali na stanowisku, że nadzór państwa nad warunkami pracy jest nieodzowny i powinien być wzmocniony, gdyż gospodarka rynkowa niesie ze sobą realne zagrożenie dla pracowników (Zieliński 2001). W konsekwencji doszło do zjawiska nadregulacji, która nie tylko utrudniała rozwój dialogu społecznego, ale także funkcjonowanie przedsiębiorstw w gospodarce rynkowej. Wykładnia sądowa zaczęła odgrywać większą rolę od prawa stanowionego, szczególnie w sprawach dotyczących dopuszczalności zawierania umów terminowych, a także zmiany i rozwiązywania umów o pracę. Coraz częściej $\mathrm{w}$ literaturze podnosi się problem związany z niskim poziomem ochrony polskich pracowników w porównaniu ze standardami obowiązującymi w innych krajach (Mitrus 2018), mimo że regulacje prawa pracy wskazywałyby na odmienną, raczej przychylną ocenę.

Zbyt daleko posunięty uniformizm prowadzi do negatywnych skutków nie tylko dla rynku pracy, ale także dla nauki prawa pracy, o czym świadczy choćby dyskusja dotycząca charakteru prawnego norm prawa pracy i pojawiająca się sugestia o ich publicznoprawnym (Musiała 2018), a wręcz administracyjnoprawnym charakterze (Sobczyk 2017). Nie wchodząc w głębszą polemikę z prezentowanymi tezami, chciałabym jedynie zwrócić uwagę na dorobek niemieckiej nauki prawa pracy, w której mimo na wskroś socjalnego charakteru przepisów, dominuje pogląd o prywatnoprawnym charakterze norm prawa pracy, a dyskusja w tym przedmiocie zakończyła się już kilkadziesiąt lat temu.

Wbrew tendencjom krajowym, uniformizm staje się zasadą ustępującą dyferencjacji, a w dalszej perspektywie również różnicowaniu. Sytuacja ta jest 
wynikiem nie tylko nowych metod zarządzania, nowoczesnych technologii, zmiany sposobu życia, ale przede wszystkim struktury przedsiębiorstw, w których dominują mali i średni pracodawcy. Znalezienie w tego typu firmach pracowników na porównywalnych stanowiskach i o podobnych kompetencjach jest stosunkowo rzadkie. Głównym problemem zatrudnionych w tego typu strukturach nie jest naruszenie zasady równego traktowania, lecz raczej brak możliwości elastycznego kształtowania sposobu świadczenia pracy.

\section{ZAKOŃCZENIE}

Powyższe rozważania prowadzą do wniosku, że prawo pracy potrzebuje różnicowania, a nie uniformizmu, dyferencjacji, a nie jednolitości. Zahamowanie różnorodności oznacza zatrzymanie procesu rozwojowego tej gałęzi prawa, a jednocześnie pozbawienie prawa pracy realnego wpływu na zmieniającą się rzeczywistość. Postulat różnorodności niesie ze sobą konieczność otwarcia się na szersze wykorzystanie zasady swobody umów w prawie pracy. Zmusza zarazem ustawodawcę do wprowadzenia nowych lub rozwinięcia istniejących instytucji, w sposób umożliwiający stronom dokonywanie wyboru i możliwość kształtowania wzajemnych relacji zgodnie z ich potrzebami i oczekiwaniami. Zarówno zasada semiimperatywnego charakteru norm prawa pracy, jak i zasada równości nie stanowią bariery dla rozwoju idei różnorodności, która nie oznacza dla nich konkurencji i nie powinna być traktowana w kategorii zagrożenia dla dobra pracowników.

\section{BIBLIOGRAFIA}

Dral, Antoni. 2017. W System prawa pracy. Czesść ogólna. Red. Krzysztof W. Baran. Warszawa: Wolters Kluwer.

Florek, Ludwik. 2003. „Granice liberalizacji prawa pracy”. W Materiaty z XIV Zjazdu Katedr Prawa Pracy i Ubezpieczeń Społecznych. Łódź: Wydawnictwo Uniwersytetu Łódzkiego.

Florek, Ludwik. 2012. „Swoboda umów w prawie pracy”. W Wolność i sprawiedliwość w zatrudnieniu. Księga pamiątkowa poświęcona Prezydentowi Rzeczypospolitej Polskiej Profesorowi Lechowi Kaczyńskiemu. Red. Michał Seweryński, Jakub Stelina. Gdańsk: Wydawnictwo Uniwersytetu Gdańskiego.

Florek, Ludwik. 2017. W System prawa pracy. Indywidualne prawo pracy. Część ogólna. Red. Grzegorz Goździewicz. Warszawa: Wolters Kluwer.

Gersdorf, Małgorzata. 2016. „Interakcje prawa cywilnego i prawa pracy na przykładzie klauzuli konkurencyjnej po ustaniu zatrudnienia”. W Prawo pracy. Między gospodarka a ochrona pracy. Księga jubileuszowa Profesora Ludwika Florka. Red. Monika Latos-Miłkowska, Łukasz Pisarczyk. Warszawa: Wolters Kluwer.

Gładoch, Monika. 2015. „Prawo pracy a umowa o zatrudnienie wspólna dla wszystkich”. Rzeczpospolita, 4.08, https://www.rp.pl/Elastycznosc-daje-prace/308049948-Prawo-pracy-a-umowa-o-zatrudnienie-wspolna-dla-wszystkich.html. 
Kijowski, Andrzej. 2002. „Zakres swobody pracodawcy w korzystaniu z zatrudnienia cywilnoprawnego". W Księga Jubileuszowa Profesora Tadeusza Zielińskiego. Red. Maria Matey-Tyrowicz, Lesław Nawacki, Barbara Wagner. Warszawa: Biuro Rzecznika Praw Obywatelskich.

Liszcz, Teresa. 2013. „Konstytucyjna zasada ochrony pracy”. W Prawo pracy. Refleksje i poszukiwania. Księga jubileuszowa Profesora Jerzego Wratnego. Red. Gertruda Uścińska. Warszawa: Instytut Pracy i Spraw Socjalnych.

Łaga, Maciej. 2016. Wielkość zatrudnienia jako kryterium dyferencjacji w prawie pracy. Warszawa: Wolters Kluwer.

Mitrus, Leszek. 2018. Wypowiedzenie umowy o prace z przyczyn dotyczacych pracownika. Warszawa: C.H. Beck.

Musiała, Anna. 2018. „Homo iuridicus prawa pracy”. Praca i Zabezpieczenie Społeczne 5: 6-12.

Salwa, Zbigniew. 2007. Prawo pracy i ubezpieczeń społecznych. Warszawa: LexisNexis Polska.

Sanetra, Walerian. 1998. „Konstytucyjne prawo do rokowań”. Praca i Zabezpieczenie Spoleczne 12: $3-9$.

Sanetra, Walerian. 2001. „Prawo pracy a polityka”. W Prawo pracy u progu XXI wieku. Stare problemy i wyzwania wspótczesności. Białystok: Wydawnictwo Uniwersytetu w Białymstoku.

Sanetra, Walerian. 2017. W System prawa pracy, Indywidualne prawo pracy. Część ogólna. Red. Grzegorz Goździewicz. Warszawa: Wolters Kluwer.

Słownik języka polskiego. 1998. Red. Mieczysław Szymczak. Warszawa: Wydawnictwo Naukowe PWN.

Sobczyk, Arkadiusz. 2017. W System prawa pracy. Czesść ogólna. Red. Krzysztof W. Baran. Warszawa: Wolters Kluwer.

Święcicki, Maciej. 1968. Prawo pracy. Teksty prawne do celów dydaktycznych. Warszawa: Państwowe Wydawnictwo Naukowe.

Wagner, Barbara. 2016. „Na marginesie problemu przydatności prawa pracy dla gospodarki”. W Prawo pracy. Między gospodarka a ochrona pracy. Księga jubileuszowa Profesora Ludwika Florka. Red. Monika Latos-Miłkowska, Łukasz Pisarczyk. Warszawa: Wolters Kluwer.

Wujczyk, Marcin. 2016. Zakaz dyskryminacji w prawie pracy. Rozważania porównawcze de lege lata $i$ de lege ferenda na gruncie polskich i brytyjskich przepisów antydyskryminacyjnych. Warszawa: C.H. Beck.

Zieliński, Tadeusz. 2001. „Zasady prawa pracy w nowym systemie ustrojowym”. Państwo i Prawo 12: $3-14$

\section{Monika Gtadoch}

\section{ABOUT THE NEED FOR DIVERSITY IN LABOUR LAW}

Abstract. There is a conviction that if labour law is to protect the employee it in its essence requires restrictions. Therefore, the principle of contract freedom should be limited. Otherwise, there will be violation of the labour law system. Otherwise, there will be violation of the labour law system. It is only a step away from the statement that freedom in labour law may pose a threat to the implementation of the basic function in labour law. In other words, the greater uniformity i.e. uniformity of institutions, the greater the certainty and effectiveness of the protective function of labour law. Meanwhile, the employee protection function cannot be a barrier to the development of labour law. The labour law of the 21 st century requires diversity. Only thanks to new forms of employment, work organization and flexibility, labour law can meet challenges of the labour market.

Keywords: freedom of contracts, labour law, freedom, diversity, uniformity, labour market. 